\title{
The Relation Between Career Barriers Faced by Teachers \& Level of Stress and Job Satisfaction
}

\author{
Yusuf İnand ${ }^{*}$ \\ Mersin Üniversity, Faculty of Education, Mersin-Turkey, \\ ORCID:0000-0003-2760-0957 \\ Şaziye Yaman \\ American University of the Middle East, Kuwalt, \\ ORCID: 0000-0002-7463-6752 \\ Mustafa Ataş \\ Republic of Turkey, Ministry of National Education, Turkey, \\ ORCID: 0000-0002-6861-8582
}

\begin{tabular}{ll}
\hline \hline Article history & This study aims to determine the relation between career barriers of \\
Received: & teachers, who have previously experienced the phenomenon? and those \\
16.04.2021 & who work in state schools, and their job satisfaction and stress level. The \\
Received in revised form: & paper also addresses the predictive power of teacher's career barriers on \\
their job satisfaction and stress level. To be able to analyse the mentioned \\
relationship, correlational survey model was used in this research. In the \\
Accepted: & study, disproportionate stratified sampling was used and 278 teachers' \\
07.08 .2021 & notions were taken into consideration. Data were gathered via the \\
Key words: & application of "Teachers' Career Barriers Scale" which was developed by \\
\hline Teacher, & Inandi and Gilic (2020), "Sources of Stress Scale", developed by \\
Career barrier, & Pehlivan (1993) and "Job Satisfaction Scale", developed by Spector \\
Job satisfaction, & (1994) and translated into Turkish by Yelboga (2009). Correlation and \\
Stress level & regression analysis were used for the collected data. As a result of the \\
& study, significant relations were found between teachers' career barriers, \\
& and their job satisfaction and stress levels; teachers' career barriers \\
& significantly have predicted their stress levels and job satisfaction. \\
Besides, one of the fast and effective ways to decrease stress levels and \\
therefore increase job satisfaction of teachers is to eliminate the career \\
barriers they encounter amongst which the most destructive sub- \\
dimensions are union and administrative barriers.
\end{tabular}

\section{Introduction}

Under the influence of new technologies, increasing competition and other environmental factors in the second half of $20^{\text {th }}$ century, human resource has become an

\footnotetext{
*Correspondency: inandiyusuf@gmail.com
} 
important power for the organizations. In parallel with new developments, there has been an increase in the demand for qualified people and due to this increase qualification of human resource has been one of the basic elements that provide stability and continuity of the organizations. Also in educational organizations, due to the foundation of almost everything, human is an important variable. When education is considered as a whole with its all levels and institutions, teachers are one of the cornerstones of this whole. When considered from this point of view, increasing the qualifications of teachers mean improving the quality of educational outcomes. Qualified education cannot be given without a qualified teacher (Aytac, Aytac, Firat, Bayram, Keser, 2001). One of the ways to increase quality is an accurate career management and planning (Tasliyan, Ari and Duzman 2011). However, teachers face many different types of difficulties due to the fact that education requires devotion, patience and intensive labour. Responsibility of teaching, neither being able to get satisfying payment nor sentimental value, heavy course load, familial responsibilities are some of the mentioned difficulties. These difficulties can put on burdens on teachers in their career steps and influence their career process in negative ways.

It is obvious that physically and mentally well-being is one of the important premises for the success of career process (Gunay and Celik 2019). People who reach their career goals are expected to be happy, feel valuable and be productive employees with increased organizational commitment level and job satisfaction. Emotions like depression, stress, exhaustion, feeling worthless, professional anxiety can be observed in people who can't be able to reach their goals. Because of these circumstances, determining the reasons that interrupt the career process have become important. The name barriers on career steps comes from the reasons of failures that people have in their career process. In the field, falling into disfavor, skill deficit, mobbing, being fired from job, stress and exhaustion, inhibition, career plateau, dual career partners, dual career, moonlight problem and gender (Aytac et al., 2001; Aytac, 2006) are accepted as barriers on career. Even barriers on career find an expression in general, it is inevitable to express that each job has its own challenges. Nevertheless, having higher responsibility than other professions and because teacher's field of working is human, teaching is one of the most difficult and stressful jobs. Katz (2015), applying Three Block Model of Universal Design for Learning with the teachers, concluded that They also believed the model improved their practice and self-efficacy related to inclusive education, reduced their workload, and improved job satisfaction. However, teachers also articulated several barriers to its implementation, including the need for collaborative planning time, differentiated resources, professional learning communities, and public education. For the reasons mentioned above, the basic hypothesis of this study is that the barriers felt and experienced on career decrease the job satisfaction by increasing stress of the teachers. In this framework, the barriers on career have been detected and the relationship between this variable and stress and job satisfaction was examined.

\section{Barriers on Career}

Human is created with a sense of continuous development, positive change and the desire to go higher from its current level. It is also expressed that one of the ways to achieve this natural desire is career planning and development. Mental, social and economic difficulties can be encountered as variables in the career development process. This situation results in not reaching the desired level in the career development process, and could disrupt the career process. These difficulties are called as barriers in the field. The concept of career 
barriers was first defined by Crites (1969). This definition contains two dimensions which are personal and environmental barriers. Low self-perception and lack of skills can be given as examples to personal barriers, and lack of mentoring and social gender stereotypes to environmental barriers. While Swanson and Tokar (1991) examined career barriers in three dimensions as social/interpersonal, attitudinal, and interactive. Family origin, future of marriage and siblings express social/interpersonal barriers; inner states such as self-concept, interests, work attitude Express attitudinal barriers; demographic features such as age and gender also Express interaction barriers (Ulas and Kizildag, 2018). Bergey, Ranellucci and Kaplan (2019) investigated the perceived costs and barriers of a teaching career among Latino preservice teachers using a mixed-method approach, and identified a range of drawbacks and barriers of a teaching career including concerns about job demands, work conditions, teacher preparation demands, emotional costs, social status, and salary, among other concerns.

In this study career barriers were examined in terms of family, economic, political, administrative, and bureaucratic barriers. It is clear that teachers face these obstacles regardless of whether they are men or women Perrewe and Nelson (2004); because there are no accurate education planning about teachers' career process in Turkey. No matter how qualified one is to look at top positions, it will be very difficult to achieve the desired goal if $\mathrm{s} / \mathrm{he}$ is not a related union member. Even if there exists a membership, it is still not possible to achieve what is desired without political support. Bureaucratic and administrative barriers also challenge teachers. Of course, the obstacles such as family, age, economic and working hours due to the teachers' own personal situations can also be mentioned. From time to time all of these obstacles can cause many negative emotions that teachers experience.

According to Perrewe and Nelson (2004), these obstacles can lead to stress and burnout in people. Career barriers can decrease people's working energy and therefore job satisfaction; can bring along stress, anxiety and exhaustion. On the other hand, job satisfaction and organizational commitment of personnel who have a successful career development can be said to increase. It is seen that people who have achieved job satisfaction, are committed to their jobs, productive, and willing to achieve the goals of their organization. This situation creates happy employees with lower stress levels, higher job and organization commitment. In this context, it can be thought that one of the reasons for decreased job satisfaction and increased stress are career obstacles.

\section{Stress}

Stress can be expressed as the psychological mood that occurs in people after various emotional summation. In another words, it is an emotional and physical condition caused by the reaction from the outside world pressure (Korkmaz, 2019). Business life is one of the major elements that causes stress in our daily life (Ahsan, Zaini, David, Shah, 2009). Workload, time management disruption, type of supervision, responsibilities, uncertainty of one's authority limit, incompatibility among employees and negative conditions in the workplace can cause stress (Iqbal \& Waseem, 2012). Additionally, Merkan (2011) stated that tall orders in organizations cause stress and anxiety; this situation also creates tension and makes the use of human resources difficult. Important thing is to be able to manage stress nowadays when there is no stress-free life on earth. Naturally, stress and anxiety are necessary in normal levels to be successful; however, when the stress level goes up, negative influences 
can occur on employees. The consequences of excessive stress and anxiety become even more important when the school environment is involved.

The relationship between the concept of stress and school organizations should be handled differently from other organizations (Aslan, 1995). Schools are places where communication and interaction are intense and sometimes overwhelming. This can cause stress on teachers. Besides, teaching responsibility can be a source of stress in itself. Excessive stress inherent in teaching can affect teacher performance negatively; can prevent goals of education and training activities. Long term stress and failure to cope with stress in teachers cause burnout (Akcamete, Kaner, Sucuoglu, 2001). Certainly, excessive stress not only causes exhaustion but also causes people to experience hopelessness and unhappiness, decreasing job satisfaction, a feeling of loneliness and alienation, and increasing anger. Stress levels should be at a certain level in order to increase job satisfaction of individuals and increase labor productivity.

\section{Job Satisfaction}

In the process from the past to the present, every organization has evaluated people from different aspects. At the beginning while the organizations do not value people sufficiently and do not pay attention to the human aspects of employees, more modern organizations took the value given to people to forefront by taking into account the differences of individuals (Inandi, Aggun, Atik, 2011). Thus, especially for the last 50 years, in order to raise the efficiency and effectiveness of organizations, intensive efforts have been made to read and understand human nature. That is because, in these developing and changing times, occupations require a human-centered working environment (Nihart, 2006). Therefore, a better understanding of human nature will both bring job satisfaction and meet the expectations of organizations more effectively. At this point, increasing job satisfaction and the efficiency of the organization depends on some variables of course. Leadership characteristics of school principals affect job satisfaction, especially when school organizations are considered in the context of the subject of the study (Keefer, 2007; Liu, 2005). If school principals can show positive leadership characteristics, there will be an increase in the job satisfaction and commitment; on the contrary often applying mobbing, seeing teachers as worthless and remaining insensitive to their desires by showing autocratic leadership features to the employees will cause the teachers to be alienated and get further away from their jobs.

Mattingly (2007), mentioned in his study that one of the core reasons of teachers' dissatisfaction is insufficient support that principals give to the teachers. When principals demostrate integrative and relevant leadership qualities, teachers have high level of job satisfaction. According to Whitehead (2006), respect of school principals for teachers and their good relations connects teachers to the organization and motivate them for work. To Hedrick (2005), though many teachers want positive organizational climate, they still feel lonely for various reasons. For teachers, in order not to experience loneliness, participation, professionalism and sharing are necessary in the organization. One of the people who will do this is the manager. If the principals want to ensure teachers' job satisfaction, they should also show instructional leadership behaviors towards teachers. Principals are also responsible for ensuring the professional development of teachers that is one of the sub-dimensions of teaching leadership behaviors of principals. For that reason, they should support teachers' 
career management and development process, and they should make efforts to remove all the obstacles in this regard. If they can manage this, a rise in teachers' job satisfaction can be expected, instead of this if teachers are precluded, they can experience stress, anger, alienation, and burnout. Also, this is not a desired situation for both the individual and the organization.

\section{Purpose of the Research}

In this study, it is aimed to reveal the relation between career barriers of teachers, job satisfaction and stress; and also, to determine the predictability of teacher's career barriers on job satisfaction and stress.

\section{Method}

\section{Model of Research}

Relational survey model was deployed in this research to reveal the relation between career obstacles/barriers of teachers, job satisfaction and stress. Relational survey model is employed to determine whether there is a change between two or more variables, and also the degree of change (Karasar, 2005). In addition, if what people think is to be learnt, this model allows getting it directly from people themselves (Christensen, Johnson \& Turner, 2015).

\section{Population and Sampling}

Population consists of 2939 teachers working in 210 public schools in the district of Dulkadiroglu in Kahramanmaras city in the 2019-2020 academic year. The scale of 278 teachers selected through disproportionate stratified sampling from the study population was taken into consideration. Sample of the study consists of 123 women, 155 men, totally 278 teachers. According to Saunders, Lewis \& Thornhill (2009), the sample of this research is in the $\% 95$ confidence and $\% 5$ error range in line with calculation for the population with a certain number.

\section{Data Collection Tools}

Three different scales were used to gather data in this study. Besides, Personal Information Form, prepared by the researchers was used to determine the demographic characteristics of the teachers.

To determine teachers' career barriers, "Teachers' Career Barriers Scale" which was developed by Inandi and Gilic (2020), was used. The mentioned scale analyzes career obstacles in five sub-dimensions. Cronbach Alpha .94 was found as a result of the reliability analysis performed on the whole scale. On a factor basis, for family barriers .86; for economic barriers .73; for political/union barriers .86; for management-related barriers .78; for bureaucratic obstacles in council of higher education Cronbach Alfa .78 has ensued. As the result of the reliability analysis which was done by researchers, Cronbach Alfa .86 was found for the whole scale. On a factor basis, for family barriers .82; for economic barriers .81; for political/union barriers .81; for management-related barriers .80; for bureaucratic barriers in council of higher education Cronbach Alfa .81 has ensued. 
"Job Satisfaction Scale", as the second data collection tool, and which was developed by Spector (1994) and translated into Turkish by Yelboga (2009) was used to determine teachers' job satisfaction. Each dimension contains 4 items and there are 36 items in total. 17 items are positive, 19 items are negative. Negative items were reverse coded by researchers. Cronbach Alfa. 78 was found as a result of the reliability analysis performed on the whole scale. On a factor basis, for wages .63 , for the probability of a higher job position .69 , for supervision .74 , for social rights .65 , for performance-based rewarding .71 , for the way the work is done .76 , for workmates .77 , for nature of work .82 and for communication sub-factor The scale examines job satisfaction in nine sub-dimensions. Cronbach Alfa .88 has ensued. As the result of the reliability analysis, which was done by researchers, Cronbach Alfa .70 was found for the whole scale. On a factor of basis, for wages .66, for the probability of a higher job position .65 , for supervision .67 , for social rights .67 , for performance-based rewarding .67 , for the way the work is done .67 , for workmates .66 , for nature of work .72 and for communication sub-factor Cronbach Alfa .66 has ensued.

To determine the stress sources of teachers, "Sources of Stress Scale" which was developed by Pehlivan (1993) was used as the third data collection tool. The scale examines job satisfaction in five sub-dimensions. These are the stresses caused by career development, work-specific, organizational role, organizational structure and climate, and business relationships. As a result of the analysis of the whole scale, Cronbach Alfa .87 was found. As a result of the reliability analysis performed by researcher, Cronbach Alfa .81 was found for the whole scale. On a factor of basis, for the stresses caused by career development .80 , for work-specific stress .79 , for stress caused by organizational role .78 , for stress caused by organizational structure .75 , for stress sub-factor caused by relationships in workplace Cronbach Alfa .75 has ensued.

\section{Data Analysis}

Correlation analysis was conducted for the relationship between teachers' career barriers and job satisfaction and stress levels. Information on whether teachers' career barriers predict job satisfaction and stress levels were determined by using multiple regression analysis. In the research, 0.05 and 0.01 were used as the level of significance.

\section{Results}

Pearson correlation and regression analyzes were used to determine the relationships between the variables of the study. Results and descriptive statistics are given in the following tables. 
Table 1. Correlation Analysis Results Regarding the Relation Between Teachers' Career Barriers and Stress

\begin{tabular}{|c|c|c|c|c|c|c|c|c|c|c|c|c|}
\hline & 1 & 2 & 3 & 4 & 5 & 6 & 7 & 8 & 9 & 10 & Ort. & $\mathrm{SS}$ \\
\hline Familial Barriers & 1 & & & & & & & & & & 3.23 & .838 \\
\hline Economic Barriers & $.386^{* *}$ & 1 & & & & & & & & & 3.51 & .794 \\
\hline Union Barriers & $.222 * *$ & $.315^{* *}$ & 1 & & & & & & & & 3.62 & .715 \\
\hline Administrative Barriers & $.142 *$ & $.345^{* *}$ & $.491 * *$ & 1 & & & & & & & 3.57 & .607 \\
\hline Bureaucratic Barriers & $.180 * *$ & $.385^{* *}$ & $.337 * *$ & $.371 * *$ & 1 & & & & & & 3.69 & .631 \\
\hline Stress from Career Development & .117 & $.151 *$ & $.438 * *$ & $.483 * *$ & $.200 * *$ & 1 & & & & & 3.81 & .715 \\
\hline Work-related Stress & $.179^{* *}$ & $.177 * *$ & $.261 * *$ & $.318 * *$ & $.120 *$ & $.470 * *$ & 1 & & & & 3.51 & .568 \\
\hline Stress from Organizational Role & $.157 * *$ & $.131 *$ & $.276^{* *}$ & $.270 * *$ & $.128 *$ & $.458 * *$ & $.551 * *$ & 1 & & & 3.39 & .605 \\
\hline Stress from Organizational Structure & $.131 *$ & $.128 *$ & $.204 * *$ & $.375 * *$ & .107 & $.368^{* *}$ & $.414^{* *}$ & $448 * *$ & 1 & & 3.27 & .791 \\
\hline Stress from Relationship in Workplace & $.127 *$ & .111 & $.214 * *$ & $.393 * *$ & $.140^{*}$ & $.406^{* *}$ & $.391 * *$ & $.424 * *$ & $.781 * *$ & 1 & 3.30 & .824 \\
\hline
\end{tabular}


In Table 1, correlation analysis results that shows the relationship between career barriers faced by teachers and stress are given. Accordingly, there is a positive meaningful relationship between the sub-dimension of the career barriers faced by teachers, family barriers and the sub-dimensions of stress, work-specific $(\mathrm{r}=.179, \mathrm{p}<.01)$, organizational role $(\mathrm{r}=.157, \mathrm{p}<.01)$, organizational structure $(\mathrm{r}=.131, \mathrm{p}<.01)$ and stress caused by relationships in workplace $(\mathrm{r}=.127, \mathrm{p}<.01)$. There is no significant relationship in the sub-dimension of stress caused by career development.

There is a positive meaningful relationship between the sub-dimension of the career barriers faced by teachers, economic barriers and the sub-dimensions of stress, career development $(\mathrm{r}=$ $.151, \mathrm{p}<.01)$, work-specific $(\mathrm{r}=.177, \mathrm{p}<.01)$, organizational role $(\mathrm{r}=.131, \mathrm{p}<.01)$ and stress caused by organizational structure $(\mathrm{r}=.128, \mathrm{p}<.01)$. There is no significant relationship in the sub-dimension of stress caused by relationships in workplace.

There is a positive meaningful relationship between the sub-dimension of the career barriers faced by teachers, union barriers and all of the sub-dimensions of stress. Accordingly, there is a positive meaningful relationship between career development $(r=.438, p<.01)$, workspecific $(\mathrm{r}=.261, \mathrm{p}<.01)$, organizational role $(\mathrm{r}=.276, \mathrm{p}<.01)$, organizational structure $(\mathrm{r}=$ $.204, \mathrm{p}<.01)$ and stress caused by relationships in workplace $(r=.214, \mathrm{p}<.01)$.

There is a positive meaningful relationship between the sub-dimension of the career barriers faced by teachers, administration-related barriers and all of the sub-dimensions of stress. Accordingly, there is a positive meaningful relationship between career development $(\mathrm{r}=.483$, $\mathrm{p}<.01)$, work-specific $(\mathrm{r}=.318, \mathrm{p}<.01)$, organizational role $(\mathrm{r}=.270, \mathrm{p}<.01)$, organizational structure $(r=.375, \mathrm{p}<.01)$ and stress caused by relationships in workplace $(r=.393, p<.01)$.

There is a positive meaningful relationship between the sub-dimension of career barriers faced by teachers, bureaucratic barriers and the sub-dimensions of stress, career development $(\mathrm{r}=.200, \mathrm{p}<.01)$, work-specific $(\mathrm{r}=.120, \mathrm{p}<.01)$, organizational role $(\mathrm{r}=.128, \mathrm{p}<.01)$ and stress caused by relationships in workplace $(\mathrm{r}=.140, \mathrm{p}<.01)$. There is no significant relationship in the sub-dimension of stress caused by organizational structure. 
Table 2. Correlation Analysis Results Regarding the Relation Between Teachers' Career Barriers and Job Satisfaction

\begin{tabular}{|c|c|c|c|c|c|c|c|c|c|c|c|c|c|c|c|c|}
\hline & 1 & 2 & 3 & 4 & 5 & 6 & 7 & 8 & 9 & 10 & 11 & 12 & 13 & 14 & Ort. & SS. \\
\hline Familial Barriers & 1 & & & & & & & & & & & & & & 3.23 & .838 \\
\hline Economic Barriers & $.386^{* *}$ & 1 & & & & & & & & & & & & & 3.51 & .794 \\
\hline Union Barriers & $.222 * *$ & $.315 * *$ & 1 & & & & & & & & & & & & 3.62 & .715 \\
\hline Administrative Barriers & $.142 *$ & $.345 * *$ & $.491 * *$ & 1 & & & & & & & & & & & 3.57 & .607 \\
\hline Bureaucratic Barriers & $.180^{* *}$ & $.385 * *$ & $.337 * *$ & $.371 * *$ & 1 & & & & & & & & & & 3.69 & .631 \\
\hline Wages-related Job Satisfaction & -.023 & -.093 & $-.242 * *$ & $-.235 * *$ & -.075 & 1 & & & & & & & & & 2.45 & .823 \\
\hline Promotion-related Job Satisfaction & -.51 & -.046 & $-.309 * *$ & $-.277 * *$ & $-.193 * *$ & $-.457 * *$ & 1 & & & & & & & & 2.52 & .749 \\
\hline Supervision-related Job Satisfaction & -.116 & $-.138 *$ & $-.203 * *$ & $-.387 * *$ & -.097 & .088 & $.183 * *$ & 1 & & & & & & & 3.10 & .810 \\
\hline Social Rights-related Job Satisfaction & -.102 & $-.154 *$ & $-.319 * *$ & $-.333 * *$ & $-.145^{*}$ & $.629 * *$ & $-.441 * *$ & $.290 * *$ & 1 & & & & & & 2.66 & .762 \\
\hline Reward-related Job Satisfaction & -.070 & -.113 & $-.329 * *$ & $-.378 * *$ & -.110 & $-.422 * *$ & $.449 * *$ & $.451 * *$ & $.558 * *$ & 1 & & & & & 2.75 & .672 \\
\hline $\begin{array}{l}\text { Job Satisfaction Related to the Way the } \\
\text { Work Is Done }\end{array}$ & -.063 & $-.133 *$ & $-.176^{*}$ & $-.189 * *$ & .097 & .054 & .088 & $-.299 * *$ & .114 & $.153 *$ & 1 & & & & 3.06 & .479 \\
\hline Workmates-related Job Satisfaction & -.058 & $-.137 *$ & $-.164 * *$ & $-.251 * *$ & -.056 & -.001 & -.061 & $.389 * *$ & $-.128 *$ & $.329 * *$ & $.180 * *$ & 1 & & & 3.47 & .707 \\
\hline Work Structure-related Job Satisfaction & -.063 & -.096 & $-.275^{* *}$ & $-.184 * *$ & -.016 & $-.380 * *$ & .207 & $.198 * *$ & $-.377 * *$ & $.477 * *$ & -.110 & $.320 * *$ & 1 & & 3.40 & .666 \\
\hline Communication-related Job Satisfaction & -.035 & .002 & -.108 & -.110 & .099 & -.103 & -.060 & $.270 * *$ & .028 & .108 & .088 & $.430 * *$ & $.222 * *$ & 1 & 3.20 & .510 \\
\hline
\end{tabular}


In Table 2, there are correlation analysis results that shows the relation between career barriers faced by teachers and Job Satisfaction. Accordingly, there are meaningful relationships between family barriers and the sub-dimensions of job satisfaction ( $p>.05)$, economic barriers and the sub-dimensions of job satisfaction to supervision $(r=-.138, p<.01)$, to social rights $(\mathrm{r}=-.154, \mathrm{p}<.01)$, to the way the work is done $(\mathrm{r}=-.133, \mathrm{p}<.01)$ and workmates-related job satisfaction $(\mathrm{r}=-.137, \mathrm{p}<.01)$. There is no significant relationship between economic barriers and the other sub-dimensions of job satisfaction.

There are meaningful relationships between the other sub-dimensions of career barriers union barrier and the sub-dimensions of job satisfactions to wages $(r=-.242, p<.01)$, to promotion $(\mathrm{r}=-.309, \mathrm{p}<.01)$, to supervision $(\mathrm{r}=-.203, \mathrm{p}<.01)$, to social rights $(\mathrm{r}=-.319, \mathrm{p}<.01)$, to award $(\mathrm{r}=-.329, \mathrm{p}<.01)$, to the way the work is done $(\mathrm{r}=-.176, \mathrm{p}<.01)$, to workmates $(\mathrm{r}=-.164$, $\mathrm{p}<.01)$, to work structure-related job satisfaction $(\mathrm{r}=-.275, \mathrm{p}<.01)$. There is no significant relation between communication sub-dimension.

There is a negative meaningful relationship between the other sub-dimensions of career barriers administrative barrier and the sub-dimensions of job satisfactions to wages $(\mathrm{r}=-.235$, $\mathrm{p}<.01)$, to promotion $(\mathrm{r}=-.277, \mathrm{p}<.01)$, to supervision $(\mathrm{r}=-.387, \mathrm{p}<.01)$, to social rights $(\mathrm{r}=-$ $.333, \mathrm{p}<.01)$, to award $(\mathrm{r}=-.378, \mathrm{p}<.01)$, to the way the work is done $(\mathrm{r}=-.189, \mathrm{p}<.01)$, to workmates $(\mathrm{r}=-.251, \mathrm{p}<.01)$, to work structure-related job satisfaction $(\mathrm{r}=-.184, \mathrm{p}<.01)$. There is no significant relation between communication sub-dimension.

There is a negative meaningful relationship between the last sub-dimension of career barriers bureaucratic barrier and the sub-dimensions of job satisfaction to promotion $(r=-.193, p<.01)$, to social rights-related job satisfaction $(\mathrm{r}=-.145, \mathrm{p}<.01)$. There is no significant relation between bureaucratic barriers and the sub-dimensions of job satisfaction. 
Table 3. Multiple Regression Analysis Results Related to the Prediction of Stress of Career Barriers Faced by Teachers

\begin{tabular}{|c|c|c|c|c|c|c|c|c|c|c|c|c|}
\hline & \multicolumn{4}{|c|}{ Career Development-related Stress } & \multicolumn{4}{|c|}{ Work-specific Stress } & \multicolumn{4}{|c|}{ Organizational Role-related Stress } \\
\hline & B & $\mathrm{SH}$ & $\beta$ & $\mathrm{T}$ & B & $\mathrm{SH}$ & $\beta$ & $\mathrm{T}$ & B & SH & $\beta$ & $\mathrm{T}$ \\
\hline Constant & 1.428 & .282 & & 5.058 & 2.154 & .248 & & 8.671 & 2.058 & .268 & & 7.685 \\
\hline Familial Barriers & .028 & .048 & .033 & .591 & .078 & .042 & .115 & 1.862 & .074 & .045 & .103 & 1.642 \\
\hline Economic Barriers & -.066 & .055 & -.073 & -1.209 & .018 & .048 & .026 & .381 & -.018 & .052 & -.023 & -.341 \\
\hline Union Barriers & .273 & .061 & .273 & 4.501 & 095 & .053 & .119 & 1.772 & 147 & .058 & .174 & 2.554 \\
\hline Administrative Barriers & .438 & .072 & .372 & 6.049 & .235 & .064 & .251 & 3.687 & .180 & .069 & .181 & 2.623 \\
\hline \multirow[t]{5}{*}{ Bureaucratic Barriers } & -.008 & .066 & -.007 & -.128 & -.040 & .058 & -.044 & -.688 & -.007 & .063 & -.007 & -.109 \\
\hline & $\mathrm{R}=.539$ & $\mathrm{R}^{2}=.290$ & & & $\mathrm{R}=.362$ & $\mathrm{R}^{2}=.131$ & & & $\mathrm{R}=.330$ & $\mathrm{R}^{2}=.109$ & & \\
\hline & $\mathrm{F}_{(5)}=22.529$ & $\mathrm{P}<.001$ & & & $\mathrm{~F}_{(5)}=8.176$ & $\mathrm{P}<.001$ & & & $\mathrm{~F}_{(5)}=6.643$ & $\mathrm{P}<.001$ & & \\
\hline & \multicolumn{4}{|c|}{ Organizational Structure-related Stress } & \multicolumn{4}{|c|}{ Relationships in Workplace-related Stress } & & & & \\
\hline & $\mathrm{B}$ & $\mathrm{SH}$ & $\beta$ & $\mathrm{T}$ & $\mathrm{B}$ & SH & $\beta$ & $\mathrm{T}$ & & & & \\
\hline Constant & 1.453 & .342 & & 4.250 & 1.269 & .353 & & 3.596 & & & & \\
\hline Familial Barriers & .086 & .058 & .091 & 1.496 & .090 & .060 & .092 & 1.519 & & & & \\
\hline Economic Barriers & -.026 & .066 & -.026 & -.397 & -.067 & .068 & -.065 & -.978 & & & & \\
\hline Union Barriers & .025 & .074 & .023 & .344 & .025 & .076 & .022 & .334 & & & & \\
\hline Administra-tive Barriers & .492 & .088 & .377 & 5.608 & .534 & .091 & .393 & 5.891 & & & & \\
\hline \multirow[t]{3}{*}{ Bureaucra-tic Barriers } & -.059 & .080 & -.047 & -.736 & -.007 & .082 & -.005 & -.081 & & & & \\
\hline & $\mathrm{R}=.387$ & $\mathrm{R}^{2}=.150$ & & & $\mathrm{R}=.404$ & $\mathrm{R}^{2}=.163$ & & & & & & \\
\hline & $F_{(5)}=9.587$ & $\mathrm{P}<.001$ & & & $\mathrm{~F}_{(5)}=10.601$ & $\mathrm{P}<.001$ & & & & & & \\
\hline
\end{tabular}


There are regression analysis results performed on stress predictions of the career barriers experienced by teachers in Table 3. Accordingly, the predictor of career barriers subdimensions over all sub-dimensions of stress $(\mathrm{p}<.01)$ is observed.

\section{Career Development-related Stress}

There is a meaningful relationship between the five sub-dimensions of the career barriers and career development-related stress sub-dimension of stress $(\mathrm{R}=.539, \mathrm{R} 2=.290$, $\mathrm{p}<.01)$. Carrier barriers sub-dimensions explain $\% 29$ of the total variance in the career development-related stress sub-dimension.

\section{Work-specific Stress}

There is a meaningful relationship between the five sub-dimensions of the career barriers and work-specific stress sub-dimension of stress $\left(\mathrm{R}=.362, \mathrm{R}^{2}=.131, \mathrm{p}<.01\right)$. Carrier barriers sub-dimensions explain \%13.1 of the total variance in the work-specific stress.

\section{Organizational Role-related Stress}

There is a meaningful relationship between the five sub-dimensions of the career barriers and organizational role-related stress sub-dimension of stress $\left(\mathrm{R}=.330, \mathrm{R}^{2}=.109\right.$, $\mathrm{p}<.01)$. Carrier barriers sub-dimensions explain \%10.9 of the total variance in the organizational role-related stress.

\section{Organizational Sutructure-related Stress}

There is a meaningful relationship between the five sub-dimensions of the career barriers and organizational structure-related stress sub-dimension of stress $\left(\mathrm{R}=.387, \mathrm{R}^{2}=.150\right.$, $\mathrm{p}<.01)$. Carrier barriers sub-dimensions explain $\% 15$ of the total variance in the organizational structure-related stress.

\section{Relationships in Workplace-related Stress}

There is a meaningful relationship between the five sub-dimensions of the career barriers and relationships-related stress sub-dimension of stress $\left(\mathrm{R}=.404, \mathrm{R}^{2}=.163, \mathrm{p}<.01\right)$. Carrier barriers sub-dimensions explain $\% 16.3$ of the total variance in the relationshipsrelated stress. 
Table 4. Multiple Regression Analysis Results Related to the Prediction of Job Satisfaction of Career Barriers Faced by Teachers

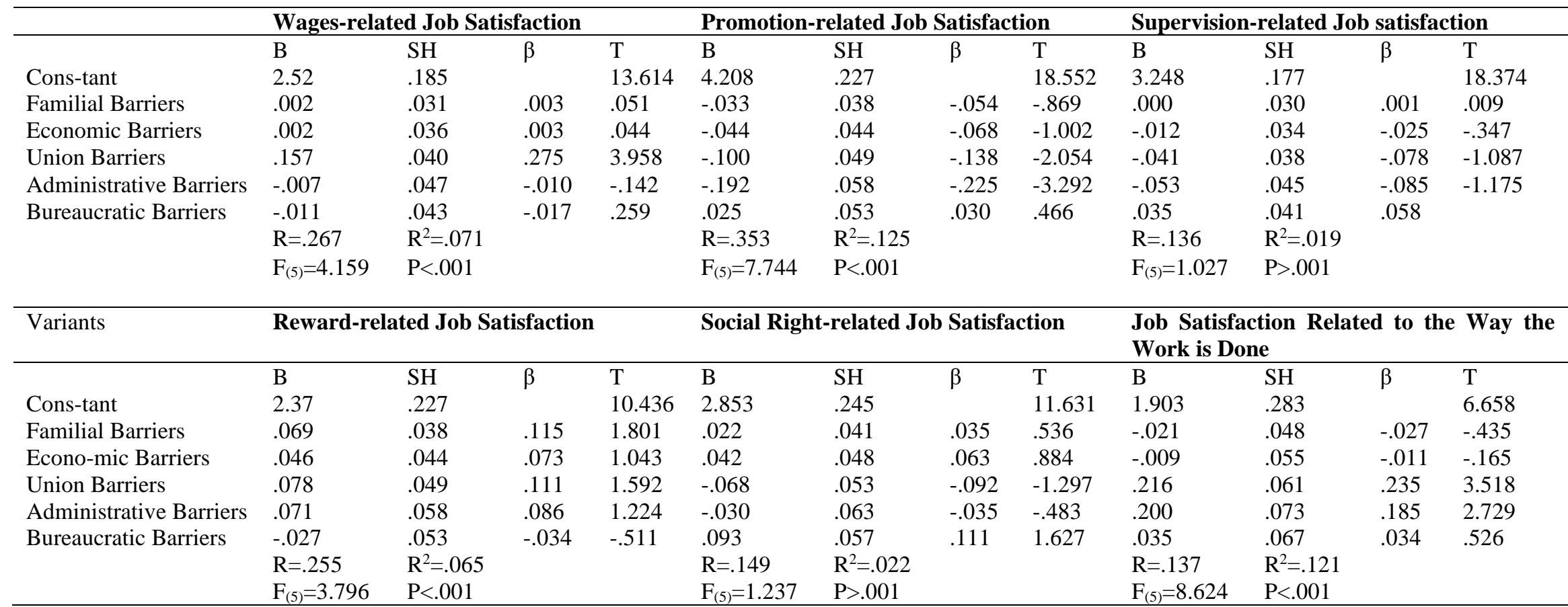


In Table 4, there are regression analysis results on the career barriers faced by teachers on predicting their job satisfaction. Accordingly, prediction of career barriers subdimensions on the sub-dimensions of job satisfaction, wages, promotion, reward, the way the job is done and communication-related job satisfaction $(\mathrm{p}<.01)$ are observed. Prediction of career barriers sub-dimensions on supervision, social rights, workmates and job nature-related job satisfaction ( $\mathrm{p}>.01)$ aren't shown in Table 4.

\section{Wages-related Job Satisfaction}

There is a meaningful relationship between career barriers sub-dimensions and wages-related job satisfaction of the job satisfaction sub-dimension $\left(R=.267, R^{2}=.071\right.$, $\mathrm{p}<.01)$. Career barriers sub-dimensions explain $\% 7$ of the total variance in wagesrelated job satisfaction.

\section{Promotion-related Job Satisfaction}

There is a meaningful relationship between career barriers sub-dimensions and promotion-related job satisfaction of the job satisfaction sub-dimension $(R=.353$, $\left.\mathrm{R}^{2}=.125, \mathrm{p}<.01\right)$. Career barriers sub-dimensions explain $\% 12.5$ of the total variance in promotion-related job satisfaction.

\section{Reward-related Job Satisfaction}

There is a meaningful relationship between career barriers sub-dimensions and reward-related job satisfaction of the job satisfaction sub-dimension $\left(R=.255, R^{2}=.65\right.$, $\mathrm{p}<.01$ ). Career barriers sub-dimensions explain \% 6.5 of the total variance in rewardrelated job satisfaction.

\section{Job Satisfaction Related to the Way the Work is Done}

There is a meaningful relationship between career barriers sub-dimensions and job satisfaction related to the way the work is done of the job satisfaction sub-dimension $\left(\mathrm{R}=.137, \mathrm{R}^{2}=.121, \mathrm{p}<.01\right)$. Career barriers sub-dimensions explain $\% 12$ of the total variance in job satisfaction related to the way the work is done.

\section{Communication-related Job Satisfaction}

There is a meaningful relationship between career barriers sub-dimensions and communication-related job satisfaction of the job satisfaction sub-dimension $(\mathrm{R}=.302$, $\left.\mathrm{R}^{2}=.091, \mathrm{p}<.01\right)$. Career barriers sub-dimensions explain $\% 9$ of the total variance in communication-related job satisfaction.

\section{Discussion, Conclusions and Suggestions}

Teacher is the one who performs educational activities. It is in the best interest of the whole society that the teacher does her/his job best. Happy teacher means happy student and efficient education. One of the ways to make teacher happiness possible is to eliminate the career barriers. Findings obtained in the study show that there is a significant relationship between job satisfaction and stress levels and career barriers 
experienced by teachers. According to this, negative meaningful relationships between career barriers faced by teachers and job satisfaction; positive meaningful relationships between career barriers and stress were found. Career barriers experienced by teachers reduce job satisfaction and increase stress levels.

\section{Relationship between Career Barriers and Job Satisfaction and Prediction Level}

There is no significant relationship between familial barriers the sub-dimensions of career barriers and the sub-dimensions of job satisfaction. This finding shows similarity to the finding of Evkaya (2019) that there is no difference in job satisfaction levels of teachers who have children compared to those who don't have. This situation suggests that teachers may perceive the constraints and disabilities related to their families separately from their job and career development.

There is a negative significant relationship between the sub-dimension of economic barriers and job satisfaction sub dimensions, supervision related, social rights-related, related to the way the work is done and workmates-related job satisfaction. For teachers, postgraduate education and professional development facilities in order to develop themselves from various aspects can be economically costly and due to the fact that it is a long-term investment tool in their education and not getting the outputs in short term may have a negative impact on teachers' job satisfaction. Teachers who do not have sufficient social rights, work under intense working conditions, and get exhausted with constant supervisions experience high levels of stress, and this can decrease their job satisfaction.

Significant high level negative meaningful relationships were found between administrative and union barriers, and the dimensions except communication subdimension of job satisfaction. The union preferences of teachers, having a different world view with senior managers and disrupting their career development with subjective criteria may affect job satisfaction negatively. In the research conducted by Pienaar and Bester (2016) on academics, it is stated that discriminatory practices should be accepted as career barriers and these practices have negative effects on job satisfaction. Apart from being a member of the relevant union, it is considered more important than merit to respond to the demands of senior managers and to work in harmony with them. Even sometimes, managers view teachers' career development process negatively and they do not encourage teachers. In this context; Ozalp, Yirci and Kocabas (2016) determined that the mentoring functions of the administrators affected teachers' job satisfaction positively. The fact that the Ministry of Education is weak in following and encouraging teachers' career development can be regarded as the sources of low job satisfaction of teachers.

There is a negative significant relationship between bureaucratic barriers and promotion-related, social rights-related sub-dimensions of job satisfaction; there are no meaningful relationships in between other sub-dimensions. This can make teachers feel worthless. According to Heyder (2019), the more the teachers believe that how s/he is important, the higher their job satisfaction are. Lack of relocation opportunities for postgraduate education, limitations in the variety of postgraduate programs, difficulties 
in the education process and quota problem lead to uncertainty in teachers' career development and negatively affects job satisfaction. This information is similar to the finding of Tasdan and Tiryaki (2008)'s promotion opportunities and uncertainty in working conditions influence job satisfaction negatively.

There is a significant predictivity on wages, promotion, reward, the way the work is done and communication-related job satisfaction of the five sub-dimensions of career barriers. The teachers think that the wages they get show that they are not appreciated, and the payment taken in return for the work done is unfair. The finding by Gunbayi and Tokel (2012) that the inadequate social opportunities and wages of teachers negatively influence job satisfaction is consistent with the finding by Eginli (2009) that wages have a priority for job satisfaction for public and private sector employees. Besides, considering the extra expenses made during the postgraduate education, the effects of career barriers on wages-related job satisfaction can be understood better. Besides considering the extra expenses made during the postgraduate education, the influence of career barriers on wages-related job satisfaction can be understood better. The perception that the teaching profession is not a career profession, the fact that doing well and being successful does not give the teacher a chance to be promoted, the idea that there are political and union obstacles to get promotion, can be explained by the effect of career barriers on promotion-related job satisfaction. Again, inefficient employee personal rights provided to teachers and inadequate additional funds may have an impact on this result. Dealing with teachers' intense work pressure due to the way the work is done, formalities and e-school businesses that consume their energies, non-ending non-educational demands of the managers, competitions and similar activities may cause to end up with decrease in teachers' job satisfaction. This finding is parallel to the finding of the study conducted by Ahsan et al. (2009), that excessive workload causes stress in academics. The fact that ministers do not share the developments that concern teachers in the institution by communicating in a healthy way, do not clearly state what they want from teachers, and that the institution is not managing perspicuously may explain the impact of career barriers on teachers' job satisfaction.

Nevertheless, there is a significant predictivity on supervision-related, social rightsrelated, workmates-related, nature of work-related job satisfaction of the five subdimensions of career barriers. It can be considered the situation that the teachers' managers are fair to them, teachers like their colleagues also they are happy to perform the teaching profession and they love the work they do, eliminates the perception of career disability. Rachmawati and Suyatno (2021) determined that the interpersonal communication skills and technical competencies of the school principal affect teachers' job satisfaction positively, this finding is consistent with the findings of the research.

Consequently, in general meaning there are negative significant relationships between career barriers faced by teachers and the job satisfaction. Job satisfaction decreases as teachers encounter career barriers. Similar results were achieved in the study conducted by Inandi and Tunc (2012) on career barriers and job satisfaction levels of women. Fiori, Bollmann and Rossier (2015) stated that employees with high career compliance feel high job satisfaction. Inandi, Tunc and Uslu (2013) found out that career barriers faced by instructors influence their job satisfaction negatively. 
M.Atas

\section{Relationship of Career Barriers with Stress and Prediction Level}

Significant positive relationships were found between career barriers subdimension family barriers and stress sub-dimensions, excluding career developmentrelated stress. This finding is consistent with the finding that family problems are one of the most important factors of stress in the study of Bucurean and Adriana (2011). Also, it is consistent with Devi and Rani (2015)'s finding that married women experience more work-family conflict than non-married women and this causes stress. This finding means that family-related career barriers increase teachers' stress levels. The neglect of the family during the career development process and the failure to fulfill the family responsibilities cause the teachers not get enough support from their spouses and children; this may have caused stress. There are significant positive relationships between career barriers sub-dimension economic barriers and stress sub-dimensions, excluding stress from relationships in workplace. Especially, being not able to reach career goals and their wasting efforts because of the economic reasons causes teachers to be stressed.

Moderately significant positive relationships were found between career barriers subdimensions administrative and union barriers and all sub-dimensions of stress. Union preferences to be effective in career development process, not being impartially evaluated in career progression, interventions of non-governmental organizations in this assessment as well as block of managers and teachers not being encouraged to develop careers by the managers can cause stress. These findings are similar to the finding of Goksel and Tomruk (2016) that the academics who are exposed to subjective principles in obtaining academic titles, being promoted, being appointed to positions experience intense stress.

Significant positive relationships were found between career barriers sub-dimension bureaucratic barriers and stress sub-dimensions, excluding organizational structurerelated stress. The difficulties in running of a postgraduate programme and teaching duties concurrently, various difficulties that school managers show in teachers' participation in classes, limited postgraduate programmes and quotas related to their field in higher education institutions may stress willing teachers in reaching these programmes.

A meaningful predictivity is seen on all sub-dimensions of stress of the five subdimensions of career barriers. The effects of career barriers on teachers' stress levels can be explained by the factors such as no support for the teachers' career development efforts, the lack of promotion and career development opportunities, the inability of teachers to make use of these opportunities fairly, heavy course load and the mental fatigue caused by the teaching profession, insufficiency of the salaries and wages received, different expectations of students, managers and parents from teachers, unfair prescriptive attitudes of managers, negative attitudes of parents and students, unresponsive managers and discipline problems. It is understood that the sub-dimension of career barriers that cause the most stress is career development-related stress. This obviously causes teachers faced career barriers to experience high level of stress. In this case, it should not be meaningful to expect teachers to be productive and effective as a result of stress. 
As a result, there are positive meaningful relationships between career barriers faced by teachers and stress. As the number of carrier obstacles faced by teachers increases, their stress levels increase and thus their career development and plans fail. In the research conducted by Choi and Jung (2018) on nurses, a significant positive relationship was found between career barriers and stress. Colligan and Higgins (2006) state that career development barriers are one of the series of factors leading to job stress. In the study which includes employees who don't encounter career barriers, conducted by Fiori et al. (2015), it was stated that employees with high career adaptation have low stress level, and those with low career adaptation have high stress level. These findings are similar to the findings of the research.

In the last instance, one of the fast and effective ways to decrease stress levels and therefore increase the job satisfaction of teachers is to eliminate the career barriers they encounter. The most destructive sub-dimensions of career barriers are union and administrative barriers. In this context, career development opportunities should be expanded and generalized to be valid for all teachers. In training and selecting education managers and academics, merit should be considered important, and criteria should be transparent and impartial. Academic development of teachers should be encouraged. In this context, legal amendments should be made urgently in the regulation regarding teachers' appointments and the teachers who study in a Postgraduate program should be able to be assigned where they are studying. In order to meet the expenses of teachers who get postgraduate education, it would be beneficial to reduce the course loads of 15 hours to 10 hours. The additional courses of the teachers who continue their doctoral or master's education should be increased as their colleagues who have been awarded as doctors and scientists. Besides that, considering teachers who continue their postgraduate education to have administrative leave one day of the week will provide great benefits during their education.

\section{Sources}

Ahsan, N., Zaini, A., David Y. \& Shah S. A. (2009). A Study of Job Stress on Job Satisfaction Among University Staff İn Malaysia: Empirical Study. European Journal of Social Sciences, 8(1), 121-131.

Akcamete G., Kaner S., Sucuoglu B. (2001). Burnout, Job Satisfaction and Personality In Teachers. Ankara: Nobel Publishing.

Aslan, M. (1995). Organizational Sources of Stress of Teachers. Doctorate Thesis, Inonu University, Malatya.

Aytac M., Aytac S, Firat Z., Bayram N., Keser A. (2001). Factors Affecting the Academic Career of Academics and Work Life as a Focus Of İndividual Attention. Uludag University Research Fund, No: 99/29.

Aytac, S. (2006). Problems In Developing Career Management Planning In Work Life. Istanbul, Ezgi Bookstore.

Bergey, B. W., Ranellucci, J., \& Kaplan, A. (2019). The Conceptualization of Costs and Barriers of a Teaching Career Among Latino Preservice Teachers. Contemporary Educational Psychology, 1-17.

Bucurean, M. \& Adriana C., M. (2011). Organızational Stress and Its Impact on Work Performance. Annals Of Faculty of Economics, 333-337. 
Choi, H. \& Jung, K. (2018). Moderating Effects of Career Decision-Making SelfEfficacy and Social Support In The Relationship Between Career Barriers and Job-Seeking Stress Among Nursing Students Preparing for Employment. Korean Acad Nurs Adm, 24(1), 61-72.

Christensen, L. B., Johnson, R. B. \& Turner, L. A. (2015). Research Methods Pattern and Analysis. (A. Aypay, Translation Editor). Ankara, Ani Publishing.

Colligan T. \& Higgins E. (2006). Workplace Stress: Etiology and Consequences. Journal Of Workplace Behavioral Health, 21(2), 89-97.

Crites, J. O. (1969). Vocational Psychology. New York: Mcgraw-Hill.

Devi, R. \& Rani, S. (2015). The Impact of Organizational Role Stress and Work Family Conflict: Diagnosis Sources of Difficulty at Work Place and Job Satisfaction Among Women İn İt Sector, Chennai, Tamil Nadu. Procedia Social and Behavioral Sciences, 219, 214-220.

Eginli, A. (2009). Job Satisfaction İ Employees: A Research on Job Satisfaction of Public and Private Sector Employees. Ataturk University Journal of Economics and Administrative Sciences, 23(3), 35-52.

Evkaya, C. (2019). Comparative Analysis of Business Ethics and Job Satisfaction Perception In High School Teachers: An Example of Pendik District In Istanbul. Doctoral Thesis, Sakarya University, Sakarya.

Fiori M., Bollmann G., Rossier J. (2015). Exploring The Path Through Which Career Adaptability İncreases Job Satisfaction and Lowers Job Stress: The Role of Affect. Journal Of Vocational Behavior, 91, 113-121.

Goksel, A. \& Tomruk, Z. (2016). The Relationship Between Stress Sources and The Behavior Shown İn Academics İn Coping with Stress. Turkey Social Research Journal, 20(2), 315-343.

Gunay, A. \& Celik, R. (2019). Predicting The Career Stress with Psychological Health and Goodwise Variables: Examples of Public Relations and Publicity Students. Suleyman Demirel University Journal of Social Sciences Institute, 2 (33), 205217.

Gunbeyi I. \& Tokel, A. (2012). Comparative Analysis of Primaru School Teachers' Job Satisfaction and Job Stress Levels. METU Journal of Social Science Research, $3(5), 77-95$.

Hedrick, C., H. (2005). Retaining Career Switchers. Unpublished Dissertation. George Mason University, Fairfax.

Heyder, A. (2019). Teachers' Beliefs About the Determinants of Student Achievement Predict Job Satisfaction and Stress. Teaching And Teacher Education, 86(11).

Iqbal, M. \& Waseem, M. A. (2012). Impact Of Job Stress on Job Satisfaction Among Air Traffic Controllers of Civil Aviation Authority: An Empirical Study from Pakistan. International Journal of Human Resource Studies, 2(2), 53-70.

Inandi, Y., Aggun, N., Atik, U. (2011). Job Satisfaction Levels of Teachers Working İn Primary School According to The Opinions of Administrators and Teachers. Mersin University Faculty of Education Journal, 6(1), 102-126.

Inandi, Y., Tunc, B. (2012). The Relationship Between Career Barriers and Job Satisfaction Levels of Female Teachers. Journal of Educational Sciences Research, 2(2), 203-222. 
Inandi, Y., Tunc, B., Uslu, F. (2013). The Relationship Between Career Barriers and Job Satisfaction of Education Faculty Instuctors. Journal Of Educational Sciences Research, 3(1), 219-238.

Inandi, Y., Gilic, F., (2020). Developing Teachers' Career Barriers Scale. Mersin University Faculty of Education Journal, 16(1).

Karasar, N. (2005), Scientific Research Methods, Ankara: Nobel Publishing.

Katz, J. (2015). Implementing The Three Block Model of Universal Design for Learning: Effects on Teachers' Self-Efficacy, Stress, And Job Satisfaction İn İnclusive Classrooms K-12. International Journal of Inclusive Education, 19(1), $1-20$.

Keefer, P., A. (2007). Job Satisfaction In Union and Nonunion Public Schools And Its Effect on Academic Achievement. Unpublished Dissertation, University of Phoenix.

Korkmaz, C. (2019). Analysis Of the Relationship Between Instructors' Perceptions of Academic Titles and Job Stress. Doctoral Thesis, Inonu University, Malatya.

Liu, L. (2005). A Study of University Physical Education Department Director Leadership Behaviour and Physical Education Teacher Job Satisfaction In Northern Taiwan. Doctoral Thesis, The University of Incarnate Word, Teksas, San Antonio.

Mattingly, J. W. (2007). A Study of Relationships of School Climate, School Culture, Teacher Efficacy, Collective Efficacy, Teacher Job Satisfaction And Intent To Turnover In The Context of Year-Round Education Calendars. Unpublished Dissertation, University of Louisville, Louisville, Kentucky.

Merkan, S. (2011). Comparative Analysis of Organizational Stress Sources of Teachers Who Work In General High School and Anatolian High Schools (Malatya Province Example). Doctoral Thesis, Inonu University, Malatya.

Nihart, C. (2006). The Personality In Leadership: The Effects on Teacher Job Satisfaction. Unpublished Dissertation, University of Phoenix, Phoenix.

Ozalp, U., Yirci R. \& Kocabas I. (2016). Mentoring Functions of School Principals as Predictor of The Level of Job Satisfaction of Assistant Principals. Kalem Journal of Education and Human Sciences 6(2), 455-494.

Pehlivan, I. (1993). Sources Of Stress In Educational Management. Published Doctoral Thesis, Ankara University, Ankara.

Perrewe P. \& Nelson D. (2004). The Facilitative Role of Political Skill. Organizational Dynamics, 33(4), 366-378.

Pienaar C. \& Bester C. (2016). Addressing Career Obstacles Within a Changing Higher Education Work Environment: Perspectives of Academics. South African Journal of Psychology, 39(3), 376-385.

Rachmawati Y. \& Suyatno, S. (2021). The Effect of Principals' Competencies on Teachers' Job Satisfaction and Work Commitment. Participatory Educational Research, 8 (1), 362-378.

Saunders M., Lewis P., Thornhill A. (2009). Research Methods for Business Students. Research Methods for Business Student, Essex, Prentice Hall.

Swanson, J. L. \& Tokar, D. M. (1991). College Students' Perceptions of Barriers to Career Development. Journal Of Vocational Behavior, 38, 92-106.

Tasdan, M. \& Tiryaki, E. (2008). Comparing Job Satisfaction Levels of Private and Public Primary School Teachers. Education And Science, 33(147), 54-70. 
M.Atas

Tasliyan, M., Ari, N. U., \& Duzman, B. (2011). Career Planning and Career Management in Human Resource Management: A Field Research on The Students of Economics and Administrative Sciences Faculty. Journal of Organization and Management Sciences, 3(2), 232-241.

Ulas O. \& Kizildag S. (2019). Developing Career Barriers Scale. Hacettepe University, Journal of Education Faculty, 34(1), 182-196.

Whitehead, R.J. (2006). The Relationship Between Urban and Suburban Teachers' Perceptions of Participation In Professional Development Activities and Job Satisfaction. Unpublished Dissertation. Wayne State University, Detroit.

Yelboga, A. (2009). Validity And Reliability of The Turkish Version of The Job Satisfaction Survey (JSS). World Applied Sciences Journal, 6(8), 1066-1072. 